\title{
THE WEIGHTED EULER IDENTITY
}

\author{
A. Aglić Aljinović AND J. PeČArić
}

Abstract. Some new weighted generalisations of Euler-type identities are given, by using weighted Montgomery identity.

Mathematics subject classification (2000): 26D15, 26D20.

Key words and phrases: Bernoulli polynomials, weighted Montgomery identity.

\section{REFERENCES}

[1] M. ABRAmowitz, I. A. STEgun (EDS), Handbook of Mathematical Functions with Formulae, Graphs and Mathematical Tables, National Bureau of Standards, Applied Math. Series 55, 4th printing, Washington 1965.

[2] A. Aglić Aljinović, M. Matić And J. PeČARIĆ, Improvements of some Ostrowski type inequalities, Journal of Computational Analysis and Applications (to appear).

[3] A. Aglić AlJinović, I. Perić And J. PeČARIĆ, Estimations of the difference of two weighted integral means via weighted Montgomery identity, Math. Inequal. \& Appl., 7, 3 (2004) 315-336.

[4] G. A. AnASTASsiou, Univariate Ostrowski inequalities, Monatshefte für Mathematik 135, (2002), 175-189.

[5] N. S. Barnett, P. Cerone, S. S. Dragomir And A. M. Fink, Comparing two integral means for absolutely continuous mappings whose derivatives are in $L_{\infty}[a, b]$ and applications, Computers and Math. With Appl. 44, (2002), 241-251.

[6] P. CERONE, S. S. DRAGOMIR, Differences between means with bounds from a Riemann-Stieltjes integral, RGMIA Res. Rep. Coll., 4, 2 (2001).

[7] P. CEROne, S. S. Dragomir, On some inequalities arising from Montgomery identity, Journal of Computational Analysis and Applications, 5, 4 (2003), 341-367.

[8] LJ. DEDIĆ, M. MATIĆ AND J. PEČARIĆ, On generalizations of Ostrowski inequality via some Euler-type identities, Math. Inequal. \& Appl., 3, 3 (2000), 337-353.

[9] V. I. KRYLOV, Approximate calculation of integrals, Macmillan, New York-London, 1962.

[10] J. PEČARIĆ, On the Čebyšev inequality, Bul. Inst. Politehn. Timisoara 25, 39 (1980), 10-11.

[11] J. PEČARIĆ, I. PERIĆ AND A. VUKELIĆ, Estimations of the difference of two integral means via Euler-type identities, Math. Inequal. \& Appl. 7, 3 (2004), 365-378. 